\title{
Elastin: mutational spectrum in supravalvular aortic stenosis
}

\author{
Kay Metcalfe ${ }^{1}$, Agnes K Rucka ${ }^{1}$, Leslie Smoot ${ }^{2}$, Guenter Hofstadler ${ }^{3}$, Gerald Tuzler ${ }^{4}$, \\ Pascal McKeown ${ }^{5}$, Victoria Siu ${ }^{6}$, Anita Rauch ${ }^{7}$, John Dean ${ }^{8}$, Nick Dennis ${ }^{9}$, Ian Ellis ${ }^{10}$, \\ William Reardon ${ }^{11}$, Cheryl Cytrynbaum ${ }^{12}$, Lucy Osborne ${ }^{13}$, John R Yates ${ }^{14}$, \\ Andrew $\mathrm{P}$ Read $^{1}$, Dian Donnai ${ }^{1}$ and Mayada Tassabehji ${ }^{1}$
}

\begin{abstract}
${ }^{1}$ University Department of Medical Genetics and Regional Genetics Service, St Mary's Hospital, Manchester, UK; ${ }^{2}$ Children's Hospital, Division of Genetics, MA; ${ }^{3}$ University of California, Department of Environmental Health Sciences, Berkeley, CA, USA; ${ }^{4}$ Department of Paediatric Cardiology, The Children's Hospital of Linz, Austria; ${ }^{5}$ The Royal Hospitals, Regional Medical Cardiology Centre, Belfast, Northern Ireland, UK; ${ }^{6}$ Medical Genetics Programme of South-Western Ontario, London, Ontario, Canada; ${ }^{7}$ Institute of Human Genetics, Erlangen, Germany; ${ }^{8}$ Department of Medical Genetics, A berdeen Royal Hospitals Trust, Scotland; ${ }^{9} \mathrm{Clinical}$ Genetics, Princess Anne Hospital, Southampton; ${ }^{10}$ Alder Hey Children's Hospital, Liverpool, UK; ${ }^{11} \mathrm{~N}$ ational Centre for Medical Genetics, Our Lady's Hospital for Sick Children, Dublin, Ireland; ${ }^{12}$ Division of Clinical and Metabolic Genetics, The Hospital for Sick Children, Toronto, Ontario; ${ }^{13}$ Department of M edicine, University of Toronto, Toronto, Ontario, Canada;

${ }^{14}$ Department of Medical Genetics, Addenbrooke's Hospital NHS Trust, Cambridge, UK
\end{abstract}

Supravalvular aortic stenosis (SVAS) is a congenital narrowing of the ascending aorta which can occur sporadically, as an autosomal dominant condition, or as one component of Williams syndrome. SVAS is caused by translocations, gross deletions and point mutations that disrupt the elastin gene (ELN) on 7q11.23. Functional hemizygosity for elastin is known to be the cause of SVAS in patients with gross chromosomal abnormalities involving ELN. However, the pathogenic mechanisms of point mutations are less clear. One hundred patients with diagnosed SVAS and normal karyotypes were screened for mutations in the elastin gene to further elucidate the molecular pathology of the disorder. Mutations associated with the vascular disease were detected in 35 patients, and included nonsense, frameshift, translation initiation and splice site mutations. The four missense mutations identified are the first of this type to be associated with SVAS. Here we describe the spectrum of mutations occurring in familial and sporadic SVAS and attempt to define the mutational mechanisms involved in SVAS. SVAS shows variable penetrance within families but the progressive nature of the disorder in some cases, makes identification of the molecular lesions important for future preventative treatments. European Journal of Human Genetics (2000) 8, 955-963.

Keywords: elastin; supravalvular aortic stenosis; mutations

\section{Introduction}

Elasticity of the skin, lungs and large blood vessels depends on the presence of elastic fibres in the extracellular matrix. Abnormalities of elastic fibres, which are composed mainly of amorphous elastic (95\%) and microfibrils, cause several cardiovascular, connective tissue and skin disorders, includ-

Correspondence: Dr May Tassabehji, Department of Medical Genetics, St Mary's Hospital, Manchester M13 0JH, UK. Tel: +44 1612766608 ; Fax: +44 161276 6606; E-mail: m.tassabehji@man.ac.uk Received 25 February 2000; revised 12 July 2000; accepted 4 August 2000 ing Marfan syndrome, supravalvular aortic stenosis (SVAS) and Cutis Laxa. ${ }^{1-4}$

SVAS is an obstructive vascular lesion with an incidence of $1 / 20000$ births, described in 1842 by Chevers, ${ }^{5}$ and was the first disorder to be associated with the elastin gene (ELN). The aortic narrowing can occur as a discrete hourglass deformity or as diffuse aortic hypoplasia and may be associated with other vascular lesions, the association with pulmonary arterial stenoses being well recognised. SVAS can occur sporadically or as an autosomal dominant condition with reduced penetrance. ${ }^{6}$ The severity of SVAS is variable but it may be progressive, leading to cardiac failure and early death 
without surgical intervention. A chromosomal translocation $\mathrm{t}(6 ; 7)(\mathrm{p} 21.1 ; \mathrm{q} 11.23)$ that segregated with SVAS in a family first suggested that mutations in the ELN gene located at 7q11.23 might be a cause of SVAS. ${ }^{7}$ Subsequently, gross deletions of ELN were identified in two cases of SVAS. ${ }^{8,9}$ We, and others, have since described point mutations in the ELN gene in both familial and sporadic cases of SVAS. ${ }^{10,11}$

SVAS also occurs as one component of Williams-Beuren syndrome (WBS), ${ }^{12}$ a complex developmental disorder caused by a deletion of about $1.4 \mathrm{Mb}$ of chromosome 7q11.23, which takes out a number of contiguous genes, including ELN.$^{13}$ Comparing WBS patients and patients with isolated SVAS, it appears that hemizygosity for elastin causes SVAS and, sometimes, peripheral artery stenosis, and hernias, but not the other features of WBS. ${ }^{14}$

In an attempt to define the molecular pathology of SVAS, we have screened 100 patients, ascertained from a range of sources in the UK and abroad, with either familial or sporadic supravalvular stenosis and/or other vascular abnormalities, for mutations in all 34 exons of the ELN gene. The relationship between the type of mutation found and the penetrance of SVAS within families as well as other possible genotype/ phenotype correlations were investigated. In this way we can attempt to identify the pathogenic mechanisms involved in this cardiovascular disorder.

\section{Materials and methods \\ Clinical ascertainment of patients}

The samples were referred in from various centres. Patients were ascertained based on cardiological diagnosis of SVAS on echocardiogram, (+/-) angiography. SVAS patients were classified as severe (s) if they had surgical procedures, moderate $(m)$ if they were still under follow-up by clinicians and mild, if stated as mild and often under no further followup.

\section{Elastin FISH and microsatellite analysis}

Elastin FISH was carried out using the Oncor WSCR probe according to the manufacturer's instructions (Appligene Oncor Lifescreen, Hertfordshire, UK). Haplotype analysis of patients was carried out by PCR amplification of genomic DNA using the following markers:

D7S2476 F: GGGCAACATAGCACGATT

D7S2476 R: CAGGAGTCAGTTAGATAAGGTCAC

ELN Helg18/19F: 5' ATG AGA CGT GGT CAA GGG TAT

ELN Helg18/19R: 5' GGG ATC CCA GGT GCT GCG GTT

LIMK1 GT F: TGGGGCAGGAGAATGATGTG

LIMK1 GT R: AGTCTTCTITGCGGGCTATGTTA

D7S613 F: CAGCCTGGGTAACAAAAGC

D7S613 R: CCTCCCTCCCTAATCCATG
All amplifications were carried out using $100 \mathrm{ng}$ of genomic DNA and 10 pmol of each primer in $20 \mu$ l reaction volumes. Cycle conditions were: $95^{\circ} \mathrm{C}$ for $2 \mathrm{~min}$, then $27 \mathrm{cycles}$ of $94^{\circ} \mathrm{C}$ for $1 \mathrm{~min}, 60^{\circ} \mathrm{C}$ for $1 \mathrm{~min}$ and $72^{\circ} \mathrm{C}$ for $1 \mathrm{~min}$, with a final extension step of $5 \mathrm{~min}$ at $72^{\circ} \mathrm{C}$. PCR products were electrophoresed on $8 \%$ polyacrylamide gels (acrylamide: $\mathrm{N}, \mathrm{N}$ ' bisacrylamide 19:1) for $3 \mathrm{~h}$ at $300 \mathrm{~V}$ then visualised by silver staining.

\section{Mutation detection and sequencing}

ELN exons were amplified using primers and amplification conditions described previously. ${ }^{10}$

In addition exon 18 was amplified using the following primers to avoid the microsatellite repeat:

\section{ELN : X18F: ATA CTC TAC TAA CCA CCC TTC TA \\ ELN : X8R: ACA CAC ACA CAC AGC CCA GCT C}

Mutations were detected by a comparison of SSCP and heteroduplex analysis, products run on $1 \mathrm{~mm}$ non-denaturing $8 \%$ polyacrylamide gels and visualised by silver staining as previously described. ${ }^{10}$ Mutations were initially characterised by fluorescent cycle sequencing (Thermo Sequenase II, Amersham, Bucks, UK) of column purified PCR products in both orientations with a matched control on an ABI 373 sequencer.

\section{Mutation screening of pedigrees}

Screening for the exon 17 mutation in family no.91 Mlul digested PCR products were separated on a $2 \%$ agarose gel and visualised by ethidium bromide staining.

Screening for the exon 6 mutation in family no. 106 BstN I digested PCR products were separated on a $2 \%$ agarose gel and visualised by ethidium bromide staining.

\section{Cloning exon 26 alleles in patient no. 11}

Exon 26 PCR amplified products from patient no. 11 were cloned using the TOPO TA cloning kit (In Vitrogen, The Netherlands) according to the manufacturer's instructions. Plasmid minipreps were made from 10 clones, using the Qiagen miniprep kits, and sequenced in both orientations using the M13 reverse and forward vector primers (fluorescent cycle sequencing, Amersham). The mutations were confirmed in at least four different clones to insure that false base changes due to Taq polymerase proofreading errors were accounted for.

\section{ARMS PCR of S442G polymorphism}

ARMSPCR was carried out using primers designed to amplify the mutant allele only:

ELN X20R: 5'CCCATCCCTTCTCAACCCATGTC

ELN X2OF ARMS M:

5'CCCTGGAGTCGCAGGTGTCCCAG

ELN X2OF ARMS N:

5'CCCTGGAGTCGCAGGTGTCCCGA 
Table 1 Spectrum of elastin gene mutations in SVAS

\begin{tabular}{|c|c|c|c|c|c|}
\hline Patient & $\mathrm{F} / \mathrm{S}$ & $\begin{array}{l}\text { Nucleotide } \\
\text { position of } \\
\text { mutation }\end{array}$ & Mutation & Effect of mutation & Clinical details \\
\hline 112 & $\mathrm{~F}$ & Exon 1 & $\Delta$ bases 1 to 28 & Del ATG start codon & SVAS(m), family history of SVAS \\
\hline 661 & $\mathrm{~F}$ & 5'UTR & $\Delta$ bases 4 to 8 & Del ATG start codon & SVAS(m), VPS, PPAS in proband, SVAS(s), PPAS in father \\
\hline 070 & $\mathrm{~S}$ & $\begin{array}{l}\text { 5'UTR } \\
\text { Exon } 9\end{array}$ & $-38 \mathrm{C}>\mathrm{T}$ & New start codon? & $\begin{array}{l}\text { SVAS(s), PPAS, brachiocephalic vessel narrowing, } \\
\text { coronary ostial stenosis }\end{array}$ \\
\hline & & $450 C>G$ & Y150X & Nonsense & \\
\hline 322 & $\mathrm{~F}$ & Exon 9 & & & SVAS in proband. AVS(s), PVS(s), PAS(s), AH in one \\
\hline 337 & $\mathrm{~F}$ & $\begin{array}{l}450 C>G \\
\text { Exon } 9\end{array}$ & Y150X & Nonsense & daughter and SVAS(m), PVS(m), PPAS in other daughter \\
\hline 332 & F & $450 C>A$ & Y150X & Nonsense & SVPS(s) and PPAS(s) \\
\hline 108 & $\mathrm{~S}$ & $\begin{array}{l}\text { Exon } 9 \\
450 C>G\end{array}$ & Y150X & Nonsense & SVAS(m), PAS. Parents have normal ECHO \\
\hline 120 & $\mathrm{~F}$ & $\begin{array}{l}\text { Exon } 10 \\
526 A>T\end{array}$ & K176X & Nonsense & SVAS(s), PPAS(m) in proband; mother has SVAS(m) \\
\hline 134 & $\mathrm{~F}$ & $\begin{array}{l}\text { Exon } 10 \\
526 A>T\end{array}$ & K176X & Nonsense & PPAS $(m)$ in proband \\
\hline 67 & $\mathrm{~S}$ & $\begin{array}{l}\text { Exon } 21 \\
1324 \mathrm{C}>\mathrm{T}\end{array}$ & Q442X & Nonsense & SVAS \\
\hline 136 & & $\begin{array}{l}\text { Exon } 21 \\
1324 \mathrm{C}>\mathrm{T}\end{array}$ & Q442X & Nonsense & SVAS, PPAS \\
\hline 290 & $\mathrm{~F}$ & $\begin{array}{l}\text { Exon } 21 \\
1324 \mathrm{C}>\mathrm{T}\end{array}$ & Q442X & Nonsense & $\begin{array}{l}\text { SVAS(s), AH, PPAS(s), PAS in proband. Half brother SVAS(s), } \\
\text { SVPS(m) }\end{array}$ \\
\hline 101 & $\mathrm{~S}$ & $\begin{array}{l}\text { Exon } 25 \\
1708 \mathrm{C}>\mathrm{T}\end{array}$ & R570X & Nonsense & SVAS(s), PPAS, bilateral inguinal hernias \\
\hline 64 & $\mathrm{~F}$ & Exon 2 & $\begin{array}{l}\text { Base } \\
105^{\wedge} 106 \text { ins T }\end{array}$ & $\begin{array}{l}\text { Frameshift/stop at } \\
\text { codon } 64 \text { (exon 4) }\end{array}$ & SVAS, Takayashus in proband. SVAS in daughter \\
\hline 106 & $\mathrm{~F}$ & $\begin{array}{l}\text { Exon } 6 \\
\text { Exon } 24 \\
\text { 1653T>A }\end{array}$ & Base 279 del T & $\begin{array}{l}\text { Frameshift/stop at } \\
\text { codon } 121 \text { (exon } 7) \\
\text { Silent mutation }\end{array}$ & $\begin{array}{l}\text { SVAS(s) proband; cousin SVAS(s) whose son has SVAS(s), } \\
\text { PPS(m) sudden death; variable penetrance } \\
\text { (see pedigree in Figure } 3 \text { ) }\end{array}$ \\
\hline 3 & $\mathrm{~S}$ & Exon 8 & Base 406 del $\mathrm{G}$ & $\begin{array}{l}\text { Frameshift/stop at } \\
\text { codon } 136 \text { (exon 8) }\end{array}$ & SVAS(s), PAS(s) \\
\hline 128 & $\mathrm{~F}$ & Exon 12 & Base 639 del G & $\begin{array}{l}\text { Frameshift/stop at } \\
\text { codon } 322 \text { (exon 18) }\end{array}$ & $\begin{array}{l}\text { SVAS(s), PPS(s) in proband; SVAS(s) in mother, variable } \\
\text { penetrance in other family members }\end{array}$ \\
\hline 340 & $\mathrm{~F}$ & Exon 16 & $\begin{array}{l}\text { Base } 8422^{\wedge} 843 \text { ins } \\
\text { TIGG }\end{array}$ & $\begin{array}{l}\text { Frameshift/stop at } \\
\text { codon } 312 \text { (exon 17) }\end{array}$ & $\begin{array}{l}\text { SVAS(s), PPAS, AH in proband. Maternal uncles SVAS(s), AH. } \\
\text { Cousin reportedly PPAS }\end{array}$ \\
\hline 80 & $\mathrm{~F}$ & Exon 18 & Base 983 del C & $\begin{array}{l}\text { Frameshift/stop at } \\
\text { codon } 333 \text { (exon 18) }\end{array}$ & $\begin{array}{l}\text { SVAS, SPS(s); father surgery for valvular PS, PPS, daughters } \\
\text { PPS }\end{array}$ \\
\hline 93 & $\mathrm{~F}$ & Exon 18 & Base 1048 del G & $\begin{array}{l}\text { Frameshift/stop at } \\
\text { codon } 463 \text { (exon 22) }\end{array}$ & SVAS in proband, father had hole in the heart \\
\hline 130 & $\mathrm{~F}$ & Exon 20 & Base 1192 del G & $\begin{array}{l}\text { Frameshift/stop at } \\
\text { codon } 463 \text { (exon 22) }\end{array}$ & SVAS and PPAS in proband, sisters, father and uncle \\
\hline 118 & $\mathrm{~F}$ & Exon 20 & Base 1260 del C & $\begin{array}{l}\text { Frameshift/stop at } \\
\text { codon } 463 \text { (exon 22) }\end{array}$ & SVAS in proband. SVAS(s) in mother \\
\hline 411 & $\mathrm{~F}$ & Exon 21 & Base 1357 del G & $\begin{array}{l}\text { Frameshift/stop at } \\
\text { codon } 463 \text { (exon 22) }\end{array}$ & $\begin{array}{l}\text { PVS(m), SVAS(m) in proband. Multiple PPAS, ASD } \\
\text { in father }\end{array}$ \\
\hline 12 & $\mathrm{~F}$ & Exon 26 & $\begin{array}{l}\text { Base } 1788^{\wedge} 1789 \\
\text { ins T }\end{array}$ & $\begin{array}{l}\text { Frameshift/stop at } \\
\text { codon } 615 \text { (exon 26) }\end{array}$ & $\begin{array}{l}\text { SVAS(s), PPAS in proband; variable familial } \\
\text { penetrance (14) }\end{array}$ \\
\hline 590 & $\mathrm{~S}$ & Exon 26 & Base 1727 del G & $\begin{array}{l}\text { Frameshift/stop at } \\
\text { codon } 674 \text { (exon 28) }\end{array}$ & $\begin{array}{l}\text { SVAS(s), PPAS, superior mesenteric artery stenosis(s), } \\
\text { coarctation and stenosis of brachiocephalic vessels }\end{array}$ \\
\hline 16 & $\mathrm{~F}$ & Exon 28 & $\begin{array}{l}\text { Base } 1989 \wedge 1990 \\
\text { ins GG }\end{array}$ & $\begin{array}{l}\text { Frameshift/stop at } \\
\text { codon } 674 \text { (exon 28) }\end{array}$ & SVAS(s), PPAS \\
\hline 69 & $\mathrm{~F}$ & Exon 3 & $\begin{array}{l}\text { Donor splice } \\
\text { Base } 163+1 \mathrm{G} \rightarrow \mathrm{T}\end{array}$ & Splicing defect & SVAS in siblings and father \\
\hline 68 & ?F & Exon 8 & $\begin{array}{l}\text { Acceptor splice } \\
\text { Base } 377-2 \mathrm{~A} \rightarrow \mathrm{C}\end{array}$ & Splicing defect & $\begin{array}{l}\text { SVAS(s) in proband. Sibling died of 'cardiac problem' } \\
\text { at } 18 \text { months }\end{array}$ \\
\hline 66 & $\mathrm{~S}$ & Exon 15 & $\begin{array}{l}\text { Acceptor splice } \\
\text { Base } 746-1 \mathrm{G} \rightarrow \mathrm{C}\end{array}$ & Splicing defect & SVAS, RAS, PAS(m) \\
\hline 91 & $\mathrm{~F}$ & Exon 17 & $\begin{array}{l}\text { Acceptor splice } \\
\text { Base } 890-1 \mathrm{G} \rightarrow \mathrm{C}\end{array}$ & Splicing defect & SVAS (see pedigree in Figure 2) \\
\hline 116 & $\mathrm{~F}$ & Intron 23 & $\begin{array}{l}\text { Base } 1501+11 \wedge 12 \\
\text { ins C }\end{array}$ & Possible splicing defect & Table continues on next page \\
\hline
\end{tabular}


Table 1 - continued from previous page

\begin{tabular}{|c|c|c|c|c|c|}
\hline Patient & $F / S$ & $\begin{array}{l}\text { Nucleotide } \\
\text { position of } \\
\text { mutation }\end{array}$ & Mutation & Effect of mutation & Clinical details \\
\hline 630 & $\mathrm{~F}$ & Intron 23 & $\begin{array}{l}\text { Base } 1501+11 \wedge 12 \\
\text { ins C }\end{array}$ & Possible splicing defect & Vascular stenoses \\
\hline 102 & $\mathrm{~S}$ & $\begin{array}{l}\text { Exon } 3 \\
163 \mathrm{G}>\mathrm{A}\end{array}$ & A55T & Missense & Isolated PPAS \\
\hline 500 & $\mathrm{~S}$ & $\begin{array}{l}\text { Exon } 30 \\
2120 C>A\end{array}$ & A707D & Missense & SVAS(m) \\
\hline 11 & $\mathrm{~S}$ & $\begin{array}{l}\text { Exon } 26 \\
1828 G>C \\
1829 G>A\end{array}$ & G610Q & Missense & SVAS(s); mutations on the same allele \\
\hline 15 & $\mathrm{~F}$ & $\begin{array}{l}\text { Exon } 13 \\
659 \mathrm{C}>\mathrm{T}\end{array}$ & P220L & Missense & SVAS(s) in proband and mother \\
\hline $\begin{array}{l}\text { Boeckel } \\
\text { et } \mathrm{al}^{24}\end{array}$ & $\mathrm{~F}$ & Exon 18 & Base 1040 del C & $\begin{array}{l}\text { Frameshift/stop in } \\
\text { exon } 22\end{array}$ & $\begin{array}{l}\text { Familial SVAS and PAS with variable penetrance, ranging } \\
\text { from mild to severe }\end{array}$ \\
\hline $\begin{array}{l}\text { Li et al }{ }^{11} \\
\text { K1179 }\end{array}$ & $\mathrm{F}$ & Exon 26 & Base 1821 del C & $\begin{array}{l}\text { Frameshift/stop in } \\
\text { exon } 28\end{array}$ & Familial SVAS \\
\hline $\begin{array}{l}\text { Li et } \mathrm{al}^{11} \\
\mathrm{~K} 2017\end{array}$ & $\mathrm{~S}$ & Exon 3 & $\begin{array}{l}\text { Donor splice } \\
\text { Base } 163+1 \mathrm{G} \rightarrow \mathrm{A}\end{array}$ & Splicing defect & SVAS \\
\hline $\begin{array}{l}\text { Li et al }{ }^{11} \\
\text { K2044 } \\
\text { K2260/ } \\
2205\end{array}$ & $\mathrm{~F}$ & Exon 16 & $\begin{array}{l}\text { Acceptor splice } \\
\text { Base } 800-3 \mathrm{C} \rightarrow \mathrm{G} \\
\text { Base } 800-2 \mathrm{~A} \rightarrow \mathrm{G}\end{array}$ & $\begin{array}{l}\text { Splicing defect } \\
\text { Splicing defect }\end{array}$ & Familial SVAS \\
\hline $\begin{array}{l}\text { Urban } \\
\text { et al }{ }^{20} \\
\text { SVAS } 1+7\end{array}$ & $\mathrm{~F}$ & Exon 16 & $\begin{array}{l}\text { Acceptor splice } \\
\text { Base } 800-3 \mathrm{C} \rightarrow \mathrm{G}\end{array}$ & Splicing defect & $\begin{array}{l}\text { Familial SVAS with variable penetrance, ranging from mild } \\
\text { to severe }\end{array}$ \\
\hline
\end{tabular}

Clinical details: F: familial; S: sporadic; (m): mild/moderate; (s): severe; SVAS: supravalvular aortic stenosis; SVPS: supravalvular pulmonary stenosis; VAS: valvular aortic stenosis; VPS: valvular pulmonary stenosis; PAS: pulmonary artery stenosis; PPAS: peripheral pulmonary artery stenosis; AH: aortic hypoplasia; ASD: atrial septal defect: RAS: renal artery stenosis; Del: deletion; ins: insertion.

Exon 2 of the elastin gene was used as an internal control for amplification. Cycling conditions were: $95^{\circ} \mathrm{C}$ for $2 \mathrm{~min}$, followed by $30 \mathrm{cycles}$ of $94^{\circ} \mathrm{C}$ for $1 \mathrm{~min}, 55^{\circ} \mathrm{C}$ for $1 \mathrm{~min}$ and $72^{\circ} \mathrm{C}$ for $1 \mathrm{~min}$, with a final extension step of $5 \mathrm{~min}$ at $72^{\circ} \mathrm{C}$. The products were separated on a $2 \%$ agarose gel and scored for the presence of the polymorphism.

\section{Results}

\section{Mutations in the ELN gene}

One hundred unrelated patients with SVAS and vascular abnormalities were screened for mutations in the elastin gene, using a combination of SSCP and heteroduplex analysis. All these patients gave a positive FISH signal with elastin probes, showing that they did not have major deletions of the ELN gene (data not shown). Mutations were identified in 35 of the patients. These are described in Table1. Additionally five common polymorphisms were identified. Other previously published SVAS mutations are also listed in Table 1 to provide a comprehensive list of mutations published to date.

\section{Premature termination mutations}

Twenty-three nonsense or frameshift mutations were detected and, if translated, would result in truncated proteins lacking the C-terminal region of elastin. The C-terminus encodes important functional domains that includes for example: exon 30 (the site of a $10 \mathrm{bp}$ element thought to control mRNA decay), and exon 34 (encodes residues required for interaction with the MAGP protein during elastogenesis (see Figure 1).

\section{Splice site mutations}

Base substitutions at the GT/AG consensus splice sites were seen in four patients: no. 66 (intron 14 acceptor, $A G>A C$ ), no. 68 (intron 7 acceptor, $A G>C G$ ), no. 69 (intron 3 donor, $\mathrm{GT}>\mathrm{TT}$ ) and no. 91 (intron 16 acceptor, $A G>C G$ ). Two families (nos 116, 630) had the same insertion of a single $C$ base, 11 bases downstream from the start of intron 23 . This variant was not seen in 200 controls and further elastin mRNA analysis would be required to see if it affects splicing. In all cases the exons flanking the altered splice site are frame-neutral, so that aberrant splicing would not be expected to disrupt the reading frame.

\section{Changes affecting initiation of translation}

Two families (nos 112 and 661) had small deletions in exon 1 encompassing the ATG initiation codon. These deletions should not prevent transcription, but lack of translation would lead to a null allele and haploinsufficiency for elastin. In patient no. 070 a novel upstream ATG codon is created at position -35 nucleotides (ACG > ATG). However, the lack of a Kozak consensus sequence ${ }^{15}$ surrounding this site suggests 


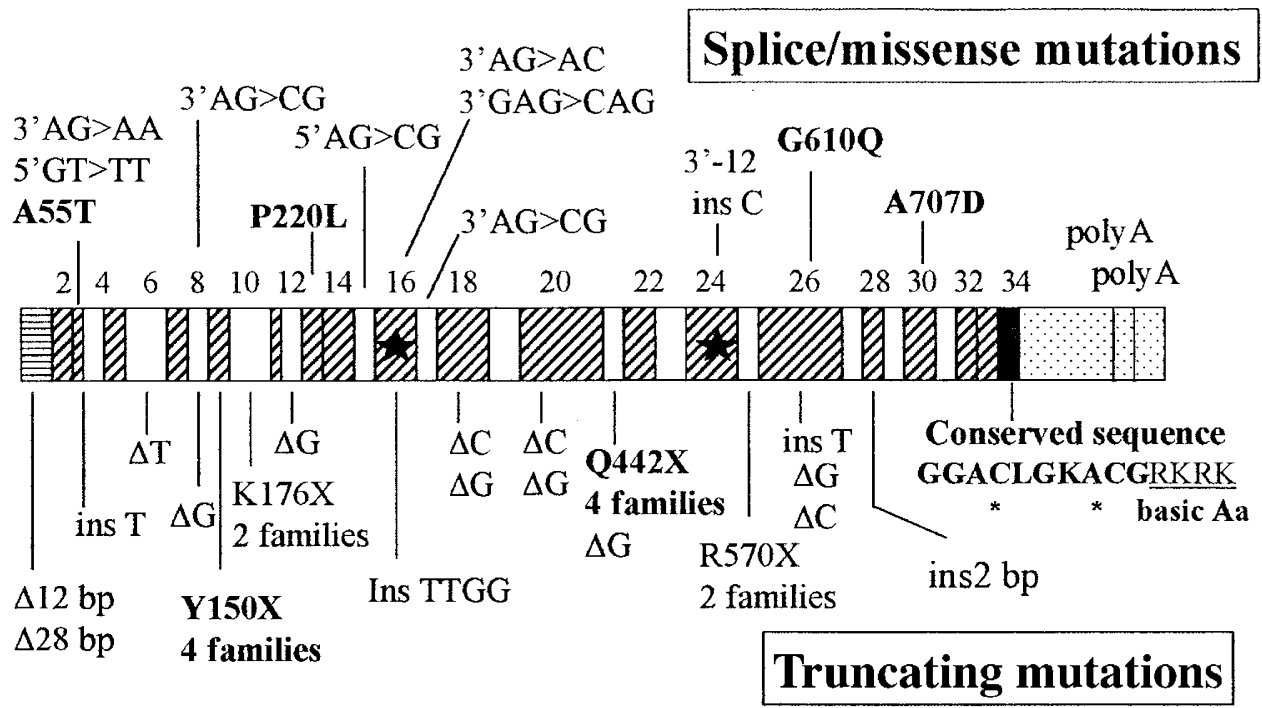

Signal sequence.

Hydrophobic domains.

Cross linking domains.

Elastin binding protein region.

Conserved Carboxy-terminus amino-acid sequence with the only 2 cysteine residues in the gene marked $(*)$ and 4 terminal basic residues.

Ins: insertion; $\Delta$ : deletion; alternatively spliced exons $13,22,23,24,26,30,32,33$.

Figure 1 ELN CDNA showing the functional domains and the mutations detected.

it is unlikely to be functional. This patient had an additional clearly pathogenic nonsense mutation, Y150X. Parental samples were not available to check whether the two changes were in cis or trans.

\section{Missense mutations}

Four patients had missense mutations not present in 200 controls. In family no. 15 the exon 13 mutation P220L was present in the proband and his affected mother. A sporadic case (patient no. 500) had A707D in exon 30. Another sporadic case (patient no. 11) had a dinucleotide substitution in exon $26, \mathrm{GG}>\mathrm{CA}$, resulting in the aminoacid substitution G610Q. Sequencing of cloned PCR products showed that the two changes were in cis. One of the two substitutions, $1828 \mathrm{G}>\mathrm{C}$, encoding G610R, is a common polymorphism (discussed below) and was present in the patient's father, but the second change occurred de novo. Finally, patient no. 102 has an apparent missense mutation, A55T, which replaces the last nucleotide of exon $3(G)$ with $(A)$. Such substitutions are known to affect the adjacent splice site because of their proximity to the consensus splice junction (GT).

\section{Recurrent mutations}

The Y150X (exon 9) and Q442X (exon 21) mutations were each seen in four apparently unrelated patients. K176X and the arguably pathogenic intron change, $1501+11 \wedge 12$ insC were each seen in two patients. Haplotype analysis of the patients using flanking and intragenic markers (D7S2476, ELN Helg18/19, LIMK1, D7S613) showed no evidence of founder effects for these mutations (data not shown).

\section{Intragenic polymorphisms}

Four novel intragenic polymorphisms were found:

Intron $4 \mathrm{G}(.96)$ or A (.04) at position $196+71$;

Intron $23 \mathrm{~T}(.64)$ or $\mathrm{C}(.36)$ at position $1501+24$;

Intron $26 \mathrm{G}$ (.93) or C (.07) at nucleotide1828, giving

the expressed polymorphism G610R;

Intron 32 C (.73) or T (.27) at position 2273-34;

A previously reported polymorphism $\mathrm{S}_{422 \mathrm{G}^{16}}$ was scored in 100 controls. We found 41 GG homozygotes, 41 SG heterozygotes and 18SS homozygotes (allele frequencies: S .385, G .615). 


\section{Intrafamilial variability}

Clinical details collected on two large families (no.91 and no. 106) with multiple affected members and defined mutations illustrate the phenotypic variability within families. Faster mutation-specific digestion tests were set up for screening other family members. Family no. 91 had 13 carriers of a splice site mutation. Five were asymptomatic, whilst other mutation carriers had symptoms ranging from mild to severe SVAS requiring surgery (Figure2). In family no. 106, mutation testing could only be performed on the proband III-4 and her sister III-7. In addition there are three sudden infant deaths, one an infant with proven SVAS and two with cardiovascular problems; two surviving children with SVAS or pulmonary stenosis, and three other possibly affected adults (Figure 3 ).

No ELN mutations were found in 64 patients with SVAS included in the study. These were clinically typical SVAS patients but the majority were sporadic. Eight cases were reported as familial but linkage support for the role of elastin was not carried out due to the small number of family members available for analysis. The SSCP/HD technique employed in this study has a $90 \%$ detection rate, so we cannot exclude the presence of point mutations in these patients. The presence of whole exon deletions within the ELN gene (not seen by FISH analysis), is also possible, and skin fibroblasts are being obtained from these patients for further screening. Alternatively, mutations in another gene could also cause SVAS.

\section{Discussion}

We have identified 35 patients with point mutations in the elastin gene many of whom have other vascular abnormalities. There appear to be mutation hotspots in exons 9 (Y150X) and 21 (Q442X - also reported in a sporadic case by $\mathrm{Li}$ et $\mathrm{al}^{15}$ ) of the ELN gene. Mutation K176X was detected in two of our families, and mutation R570X was also described in a sporadic SVAS case by Li et al. ${ }^{11}$ None of these families are known to be related and we found no evidence for a founder effect in our cases. Marked intra and interfamilial variation in phenotype is seen and there does not appear to be any good genotype-phenotype correlation, ie cases with missense mutation or splicing were just as likely to have severe SVAS as cases with truncating mutations. Disease severity within our SVAS families has varied from asymptomatic carriers of the mutation, to individual sdying in infancy from severe cardiac disease. Long term follow-up of aortic and pulmonary vascular lesions in WBS patients with SVAS has shown that individuals with moderate pressure gradients (exceeding $20 \mathrm{~mm} \mathrm{Hg}$ ) can present with pressure increases later in life, often requiring surgical intervention for the life-threatening vascular narrowing. ${ }^{17,18}$ Isolated SVAS may also be progressive and such patients require follow-up but the situation with regard to monitoring of mutation carriers with no apparent cardiovascular abnormalities is not resolved.
Two mechanisms for the pathology of SVAS can be proposed: the defects in elastin could be quantitative (haploinsufficiency for elastin) or qualitative (aberrant tropoelastin resulting in abnormal elastic fibres).

The hypothesis of a quantitative defect appears the most attractive because hemizygosity for elastin is al ready established as the mechanism for SVAS in patients with partial deletions involving ELN and in WBS. ${ }^{13}$ All classic WBS patients described are hemizygous for the elastin gene, but there is considerable variability in the severity of vascular lesions seen. Variable penetrance is typical of diseases associated with haploinsufficiency, where genetic background is expected to have a major modifying effect on development of the phenotype.

Functional hemizygosity al so appears to be the mechanism by which the majority of the SVAS point mutations exert their effect. Mutations affecting the ELN translation start site are essentially null alleles (6\%), and the truncating mutations (66\%) probably result in haploinsufficiency for elastin through nonsense mediated mRNA decay. ${ }^{19}$

It is not, however, clear if splicing and missense mutations would result in a simple loss of function. These mutations could result in exon skipping, or frameshifts through activation of cryptic splice sites. Indeed, Urban et $\mathrm{al}^{20}$ have described a SVAS patient with an acceptor splice site mutation that causes both exon skipping and activation of a cryptic splice, leading to a frameshift. Because the elastin gene has many small in-frame exons, exon skipping should be well tolerated, especially since elastin undergoes naturally occurring alternative splicing in vivo. It is worth noting that all the splicing mutation s we detected at the consen sus splice junctions are predicted to induce skipping of exons not normally spliced out. This suggests that they are important for the structural integrity of the elastic matrix and their exclusion is likely to be pathogenic. If abnormal tropoelastin proteins are synthesised they could interfere with elastic fibre assembly in a dominant negative manner, resulting in aberrant fibre formation during vasculogenesis and SVAS.

The role of the missense mutations in the pathology of SVAS is more intriguing. Three occur in exons reported to be spliced out in vivo (exons 13, 26 and 30). ${ }^{20,21}$ Alternative splicing-out of a proportion of these mutated exons should result in some degree of phenotypic rescue; however, all three patients had severe SVAS. One explanation could be that the missense mutations activate cryptic splice sites that induce additional splicing out of that exon. This could upset the overall balance of tropoelastin isoforms present at certain developmental stages, which may be important for tissuespecific elastic fibre assembly. In fact, a specific element within exon 30 of tropoelastin mRNA has been shown to be involved in posttranscriptional regulation of elastin production in mature tissue, ${ }^{22}$ and increased splicing out of this exon may have pathogenic consequences on tropoelastin expression during development. 
A.

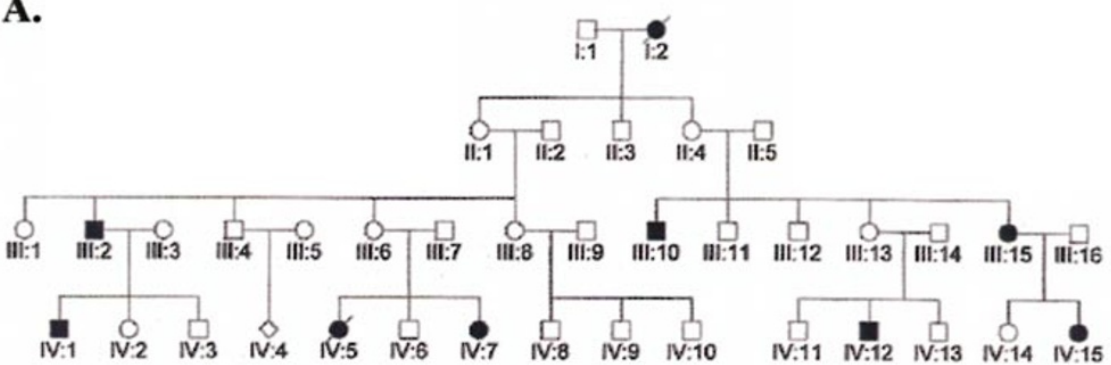

C i.

T $T$ T T C A G G C G T

100

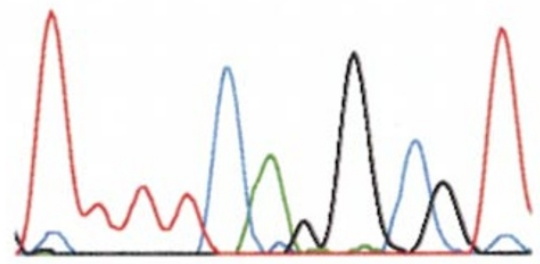

ט

ii.

T $T$ T T C A C G C G T

100

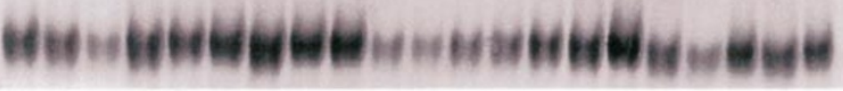

D.
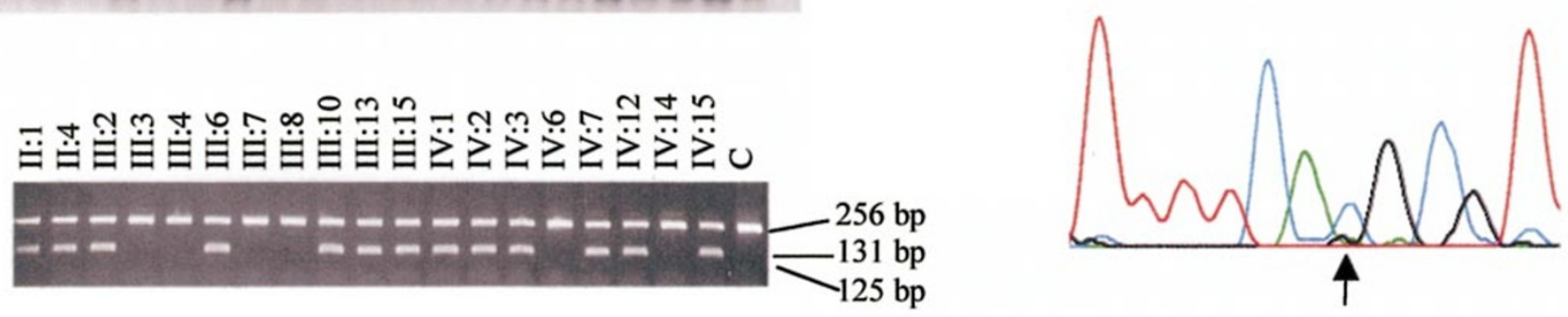

Figure 2 Pedigree and mutation analysis of family no. 91 A Family pedigree III-2, III-10, III-15, IV-7: severe SVAS requiring surgery; II-4, IV-12: moderate SVAS; IV-1, IV-15: mild SVAS; III-13, IV-2, IV-3, IV-14: no detected SVAS; II-1 III-3; III-4; III-6; III-7; III-8; IV-6: no reported vascular abnormalities B Heteroduplex analysis of exon 17 PCR product, showing a shift in the affected family members and some not reported with vascular problems; an indication of variable penetrance C Double strand sequence analysis of exon 17 shows: $\mathbf{i}$ normal mother III:2, and ii proband IV:1 with an acceptor splice site mutation at base 890-1 G $\rightarrow$ C base substitution D Confirmation of the mutation by Mlul digest analysis. An Mlul restriction site is created in the presence of the mutation resulting in two bands ( $131 \mathrm{bp}+125 \mathrm{bp}=$ mutant allele; $256 \mathrm{bp}=$ normal allele). Normal members of the family are homozygous for the normal allele ( $256 \mathrm{bp}$ band); affected members are heterozygous for the normal and mutant allele ( $256 \mathrm{bp}, 131 \mathrm{bp}$ and $125 \mathrm{bp}$ bands seen). 
A.

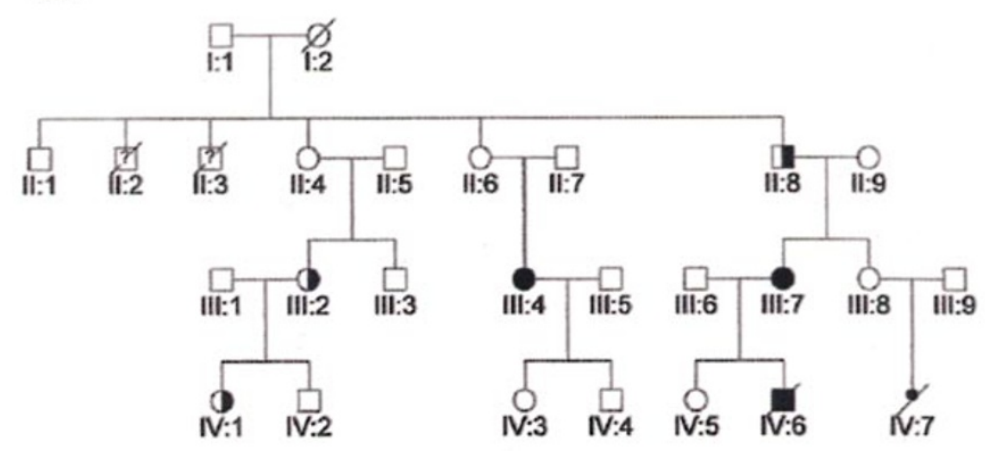

B.

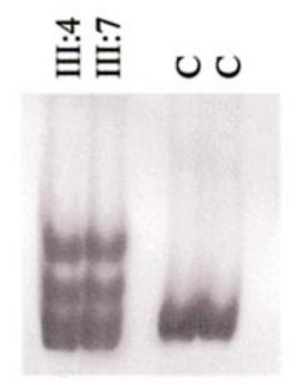

C i.
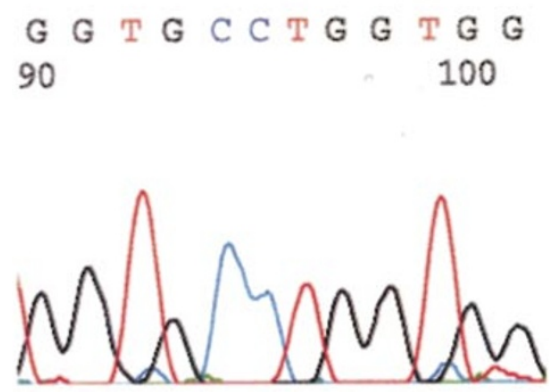

ii.
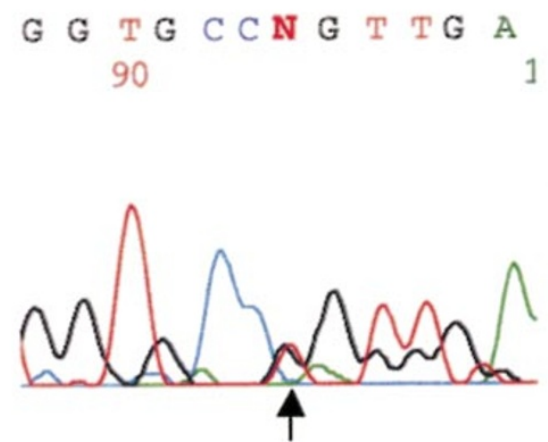

Figure 3 Pedigree and mutation analysis of family no. 106 A Family pedigree II-2, II-3: died suddenly in infancy; II-8: chronic lung disease, heart murmur; II-9: emphysema; III-2: cardiac murmur; III-4, III-7, IV-1: severe SVAS; IV-2: pulmonary stenosis; IV-3, IV-4: normal; IV-6: severe SVAS, mild pulmonary stenosis, peripheral pulmonary stenosis and minor biventricular hypertrophy, died in infancy B Heteroduplex analysis of exon 6 showing a shift in the affected family members tested: III-4, III-7; C:

controls C Double strand sequence analysis of exon 6 shows i Control individual and ii proband III:4 with a single base deletion (T) at base279, giving a frameshift D Confirmation of the mutation by BstNI digestion. The T base deletion destroys a BstNI site that normally cleaves the $253 \mathrm{bp}$ product into fragments of $136 \mathrm{bp}$ and $117 \mathrm{bp}$. The mutant $253 \mathrm{bp}$ allele is present only in the affected individuals, not in the controls (C).

The physiological consequences of haploinsufficiency for elastin can be followed in studies on hemizygous mouse knockouts $\left(\mathrm{ELN}^{-1+}\right) \cdot{ }^{23}$ Both humans and mice respond to ELN hemizygosity during development, by increasing the number of elastic lamellar units in their aorta, thereby increasing the risk of obstructive vascular disease. Whether aberrant tropoelastin and the formation of abnormal elastic fibres would also lead to SVAS via the same physiological mechanism remains to be determined, but we expect that would be the case. Future work will concentrate on providing evidence for the existence of a dominant negative mechanism for the pathology of SVAS.

\section{Acknowledgements}

We would like to thank the patients and clinicians involved in the study for their co-operation. MT was supported by the Wellcome Trust (grant 045998) and KM by the Birth Defects Foundation (UK).

\section{References}

1 Ramirez F, Gayraud B, Pereira L: Marfan syndrome: new clues to genotype-phenotype correlations. Ann Med 1999; 31(3): 202-207.

2 Williams JC, Barrat-Boyes BG, Lowe JB: Supravalvular aortic stenosis. Circulation 1961; 24: 1311-1318.

3 Tassabehji M, Metcalfe K, Hurst J et al: An elastin gene mutation producing abnormal tropoelastin and abnormal elastic fibres in a patient with autosomal dominant cutis laxa. Hum Mol Genet 1998; 7: 1021-1028.

4 Zhang MC, He L, Giro M, Yong SL, Tiller GE, Davidson JM: Curtis laxa arising from frameshift mutations in exon 30 of the elastin gene (ELN). J Biol Chem 1999; 274: 981-986.

5 Chevers N: Observations on the disease of the orifice and valves of the aorta. Guys Hosp Rep 1842; 7: 387-421.

6 Rivera H, Zavala C, Hernandex-Franco A, Bustamante-Cruz F, Cantu JM: Familial occurrence of supravalvular aortic stenosis. Rev Invest Clin 1979; 31(2): 163-167.

7 Curran ME, Atkinson DL, Ewart AK, Morris CA, Leppert MF, Keating MT: The elastin gene is disrupted by a translocation associated with supravalvular aortic stenosis. Cell 1993; 73: 159-168. 
8 Ewart AK, Jin W, Atkinson D, Morris CA, Keating MT: Supravalvular aortic stenosis associated with a deletion disrupting the elastin gene. J Clin Invest 1994; 93: 1071-1077.

9 Olson TM, Michels VV, Urban Z et al: A $30 \mathrm{~kb}$ deletion within the elastin gene results in familial supravalvular aortic stenosis. Hum Mol Genet 1995; 4: 1677-1679.

10 Tassabehji M, Metcalfe K, Donnai D et al: Elastin: genomic structure and point mutations in patients with supravalvular aortic stenosis. Hum Mol Genet 1997; 6: 1029-1036.

11 Li DY, Toland AE, Boak BB et al: Elastin point mutations cause an obstructive vascular disease, supravalvular aortic stenosis. Hum Mol Genet 1997; 6: 1021-1028.

12 Morris CA, Demsey SA, Leonard CO, Dilts C, Blackburn BL: The natural history of Williams syndrome: physical characteristics. J Pediatr 1988; 113: 318-326.

13 Ewart AK, Morris CA, Atkinson D et al: Hemizygosity at the elastin locus in a developmental disorder, Williams syndrome. Nat Genet 1993; 5(1): 11-16.

14 Tassabehji M, Metcalfe K, Karmiloff-Smith A et al: Williams syndrome: Using chromosomal microdeletions as a tool to dissect cognitive and physical phenotypes. Am J Hum Genet 1999; 64: 118-125.

15 Kozak M: Interpreting cDNA sequences: some insights from studies on translation. Mamm Genome 1996; 7(8): 563-574.

16 Tromp G, Christiano A, Goldstein N et al: A to $G$ polymorphism in ELN gene. Nucleic Acids Res 1991; 19(15): 4314

17 Wessel A, Pankau R, Kececioglu D, Ruschweski W, Bursch JH: Three decades of follow-up of aortic and pulmonary vascular lesions in the Williams-Beuren syndrome. Am J Med Genet 1994; 52(3): 297-301.
18 Peter M, Hoffman A, Parker C, Luscher T, Burckhardt D: Progression of aortic stenosis. Role of age and concomitant coronary artery disease. Chest 1993; 103(6): 1715-1719.

19 Dietz HC, Valle D, Francomano CA, Kendzior RJ, Pyeritz RE, Cutting GR: The skipping of constitutive exons in vivo induced by nonsense mutations. Science 1993; 259: 680-683.

20 Urban Z, Michels VV, Thibodeau SN, Donis-Keller H, Csiszar K, Boyd CD: Supravalvular aortic stenosis: a splice site mutation within the elastin gene results in reduced expression of two aberrantly spliced transcripts. Hum Genet 1999; 104(2): 135-142.

21 Indik Z, Yeh H, Ornstein-Goldstein $\mathrm{N}$ et al: Alternative splicing of human elastin mRNA indicated by sequence analysis of cloned genomic and complementary DNA. Proc Natl Acad Sci USA 1987; 84: $5680-5684$.

22 Zhang M, Pierce RA, Wachi H, Mecham RP, Parks WC: An open reading frame element mediates posttranscriptional regulation of tropoelastin and responsiveness to transforming growth factor betal. Mol Cell Biol 1999; 19(11): 7314-7326.

23 Li DY, Faury G, Taylor DG et al: Novel arterial pathology in mice and humans hemizygous for elastin. J Clin Invest 1998; 102(10): 1783-1787.

24 Boeckel T, Dierks A, Vergopoulos A et al: A new mutation in the elastin gene causing supravalvular aortic stenosis. Am J Cardiol 1999; 83(7): 1141-1143, A9-10. 